\title{
Ground beetles (Coleoptera: Carabidae) diversity from pastures in Southern Bulgaria
}

\author{
Teodora Teofilova $\ddagger$, Ivailo Todorov $\ddagger$, Milka Elshishka§, Vlada Peneva§ \\ $\ddagger$ Institute of Biodiversity and Ecosystem Research, Bulgarian Academy of Sciences, Sofia, Bulgaria \\ $\S$ Bulgarian Academy of Sciences, Sofia, Bulgaria
}

Corresponding author: Teodora Teofilova (oberon zoo@abv.bg)

Received: 05 Sep 2019 | Published: 05 Sep 2019

Citation: Teofilova T, Todorov I, Elshishka M, Peneva V (2019) Ground beetles (Coleoptera: Carabidae) diversity

from pastures in Southern Bulgaria. ARPHA Conference Abstracts 2: e46325. https://doi.org/10.3897/aca.2.e46325

\section{Abstract}

This study aimed at clarifying the species composition and ecological structure of carabids, associated with active pastures. Field work was carried out in 2017 and 2018. Pitfall traps (5 in each site) were set in 10 sampling sites in Thracean Lowland and Sarnena Sredna Gora Mts. Captured beetles belonged to 90 species and 33 genera, representing $12 \%$ of the species and $26 \%$ of the ground beetle genera occurring in Bulgaria. The most diverse was genus Harpalus (22 species), followed by the genera Amara (7 species), Microlestes (6 species), Ophonus (6 species) and Parophonus (5 species). Twenty species were new for the region of the Thracean Lowland: Amara fulvipes (Audinet-Serville, 1821), Anisodactylus binotatus (Fabricius, 1787), A. intermedius Dejean, 1829, Apotomus clypeonitens Müller, 1943, Calathus cinctus Motschulsky, 1850, Carterus gilvipes (Piochard de la Brûlerie, 1873), Gynandromorphus etruscus (Quensel en Schönherr, 1806), Harpalus fuscicornis Ménétriés, 1832, H. subcylindricus Dejean, 1829, Microlestes apterus Holdhaus, 1904, M. corticalis (L. Dufour, 1820), M. fulvibasis (Reitter, 1901), M. maurus (Sturm, 1827), M. minutulus (Goeze, 1777), Notiophilus laticollis Chaudoir, 1850, Pangus scaritides (Sturm, 1818), Parophonus laeviceps (Ménétriés, 1832), P. planicollis (Dejean, 1829), Polystichus connexus (Geoffroy in Fourcroy, 1785) and Pterostichus strenuus (Panzer, 1796). Twenty species were new for the whole Sredna Gora Mts.: Acinopus picipes (Olivier, 1795), A. megacephalus (P. Rossi, 1794), Amara anthobia A. Villa et G. B. Villa, 1833, Ditomus calydonius (P. Rossi, 1790), Harpalus albanicus Reitter, 1900, H. angulatus Putzeys, 1878, H. attenuatus Stephens, 1828, H. dimidiatus (P. Rossi, 
1790), H. flavicornis Dejean, 1829, H. pumilus Sturm, 1818, H. pygmaeus Dejean, 1829, $H$. subcylindricus Dejean, 1829, H. tardus (Panzer, 1796), H. signaticornis (Duftschmid, 1812), Lebia scapularis (Geoffroy, 1785), Microlestes fissuralis (Reitter, 1901), M. fulvibasis (Reitter, 1901), M. maurus (Sturm, 1827), M. minutulus (Goeze, 1777) and Ophonus sabulicola (Panzer, 1796). Fourty-one species were new for the region of the Sarnena Sredna Gora. Genus Apotomus, Gynandromorphus, Pangus and Polystichus were new geographic records for Thracean Lowland. Genera Acinopus and Ditomus were new for the Sredna Gora Mts. Fourteen life form categories were established (9 zoophagous and 5 mixophytophagous). The analysis of the life forms showed a slight predominance of the mixophytophages (53 species; 59\%) over the zoophages (37 species; $41 \%$ ). Microlestes minutulus was a constant species occurring in all sampling sites.

\section{Keywords}

carabids, agrocoenoses, new records, diversity

\section{Presenting author}

Teodora Teofilova

\section{Presented at}

$\mathrm{V}^{\text {th }}$ International Congress on Biodiversity: „Taxonomy, Speciation and Euro-Mediterranean Biodiversity"

\section{Acknowledgements}

The present study was carried out thanks to the financial aid and in parallel with the implementation of the Project BiodivERsA-FACCE2014-47 "SusTaining AgriCultural ChAnge Through ecological engineering and Optimal use of natural resources (STACCATO)" and Project H-18-TTEO-010 "Study of the faunistic diversity and assessment of the condition and ecosystems services in different types of model ecosystems in the Sarnena Sredna Gora Mts." 